Asian J. Med. Biol. Res. 2016, 2 (1), 9-12; doi: 10.3329/ajmbr.v2i1.27562

\author{
Asian Journal of \\ Medical and Biological Research \\ ISSN 2411-4472 (Print) 2412-5571 (Online) \\ www.ebupress.com/journal/ajmbr
}

\title{
Article \\ Feeding and breeding management system of goat at central and southern regions of Bangladesh
}

\author{
Md. Panir Choudhury ${ }^{1}$, Anguara Khatun ${ }^{2}$, Md. Shamsul Hossain ${ }^{3}$ and Farukul Islam ${ }^{3 *}$ \\ ${ }^{1}$ Bangladesh Livestock Research Institute, Savar, Dhaka-1341, Bangladesh \\ ${ }^{2}$ Department of Poultry Science, Bangladesh Agricultural University, Mymensingh, Bangladesh \\ ${ }^{3}$ Department of Animal Breeding and Genetics, Bangladesh Agricultural University, Mymensingh, Bangladesh \\ *Corresponding author: Farukul Islam, Department of Animal Breeding and Genetics, Bangladesh Agricultural \\ University, Mymensingh, Bangladesh. E-mail: farukkrishibid@gmail.com
}

Received: 02 January 2016/Accepted: 02 February 2016/Published: 31 March 2016

\begin{abstract}
Data were collected to study the feeding and breeding management system of goat from the villages of Mymensingh, Barguna and Patuakhali districts in Bangladesh through direct interviewing method using a pre-structured questionnaire. The research work was conducted from June to July 2014. Most of the goat rearing farmers in central and southern region of Bangladesh reared goats in semi-intensive system and kept their goats at goat's house. Farmers took winter care and took bath of their goats during summer. Maximum farmers (82\%) of central region supplied concentrate feed but $61 \%$ farmers of southern region did not supply concentrate to their goat. Farmers (82\%) of central region provided particular feeder but $67.7 \%$ farmers of southern region did not provide feeder during concentrate feeding. Tube well (84\%) was the main source of water of goat at central part of Bangladesh. But main sources of water in southern region were (46.3\%) tube well and (51.2\%) pond. All farmers of central region did not keep buck but only 19.5\% farmers of southern region kept buck for breeding their female goat. Ninety two percent famers of central part of Bangladesh and 70.7\% farmers of southern region used village buck for breeding their does. All buck keeping farmers at central region received service charge during breeding and they also practiced close breeding method. Most of $(73.2 \%)$ the buck keeping farmers at southern region of Bangladesh received service charge of buck and they did not practice close breeding system. So, the present study might be suggested that farmers at central region were more careful of their goats in terms of feeds, feeding, water sources selection and watering but farmers at southern region were more aware about buck keeping and inbreeding depressions in their goats.
\end{abstract}

Keywords: goat; feeds and feeding; breeding; management

\section{Introduction}

The export earnings from leather and leather goods is $4.3 \%$ of the total export and the current contribution of livestock subsector to overall GDP is about $2.73 \%$. Interestingly, $20 \%$ of the population is directly and $50 \%$ is partly dependent on livestock sector in Bangladesh (Draft Sixth Five Year Plan, 2010). Skins of goats are used to make mats, foot wear, water/grain containers, tents and drums (Peacock, 2005). Black Bengal goats found in hilly area differ in morphology and productivity from Black Bengal goat found in the plain land (Faruque, 2009). Goat is a very important and promising animal genetic resources in the developing countries, especially in Asia and Africa (Afroz, 2007). There were 767.93 million of goats in the world. Asia had the largest population of goats $(63.66 \%$ of world population), within which $35.36 \%, 25.46 \%, 10.79 \%$ and $7.05 \%$ found in China, India, Pakistan and Bangladesh, respectively. These countries together possessed about $71.61 \%$ of the population of goats in Asia. Bangladesh had the $4^{\text {th }}$ highest population of goat among the Asiatic countries (FAOSTAT, 2009). Bangladesh possesses approximately 34.5 million goats at present (FAO, 2003; DLS, 2004) which is about $4.49 \%$ of the total population in the world. Goats stand second in number among the ruminant species in Bangladesh. A Total of 55, 91,493 household representing 31.36\% possesses goat in Bangladesh. The 
average number of goats per household is about 2.31 and they are mostly reared by landless, small and medium farmers. Goats play a unique role in supporting some of the poorest people in Bangladesh and can play a powerful role in lifting them out of poverty towards prosperity (Amin, 2000). Feeding and breeding are the two most important management practices to explore the production potentialities of livestock, especially for goats. So, the present study was conducted to know the present status of feeding and breeding management system of goat at central and southern region of Bangladesh.

\section{Materials and Methods}

The present research was conducted at the villages of Mymensingh (central region) and Barguna and Patuakhali districts (Southern region) in Bangladesh. Data were collected in direct interviewing method (randomly) from 50 farmers at Sadar upazila of Mymensingh district and 41 farmers at Amtoli and Patharghata upazila under Barguna district and Kolapara upazila under Patuakhali district of Bangladesh where a large number of goats are raised using pre-structured questionnaire. The research work was conducted from June to July 2014. Survey sheet contain information like rearing system, feeding system, feed type, watering system, sources of buck, mating system and grazing etc. The statistical design of the study was unbalanced factorial in nature because the numbers of observations in different traits were unequal. Collected information related about feeding and breeding of goat was loaded and stored on to the Excel spread sheet. Then data were analyzed for having frequency and percentage through descriptive statistics menu under the Statistical Package for the Social Sciences version 14.0 (SPSS, 2005).

\section{Results and Discussion}

\subsection{Rearing management system}

Farmers (100\%) of central region reared their goat in semi intensive system but $80.5 \%$ farmers of southern reared their goat in semi intensive system. Few (12.2\%) farmers of central region reared goat in free range system. Most $(68 \%$ and $75.6 \%)$ of the farmers of central and southern region kept their goat at goat's house beside this, $16 \%$ and $19.5 \%$ farmers of central and southern region also kept goat at veranda of farmer's living house. Most of the farmers of central and southern region took extra care of their goats during winter season by providing bedding materials. Maximum farmers in the surveyed areas took bath of their goats during summer season. Most of the farmers ( $82 \%$ and $56.1 \%$ ) of central and southern region of Bangladesh did not take bath of their goats, only $18 \%$ and $43.5 \%$ farmers took bath of their goats during winter season. Maximum farmers $(80.5 \%)$ reared goats in semi-intensive system but few farmers $(7.3 \%)$ used confinement system of rearing, while $12.2 \%$ farmers used free range system in the southern region (Hossain et al., 2015). They also found that most $(100 \%)$ of the goat farmers took bath of their goats in the summer season but only $4.9 \%$ farmers took bath of their goats daily in the summer season. Pattamarakha et al., (1997) reported that, most of the farmers did not have shelters for their goats.

\subsection{Feeding management}

Eighty two percent farmers of central region supplied green grass and concentrate but $61 \%$ farmers of southern region supplied only green grass to their goats. Most of (80\% and 65.9\%) the farmers of central and southern region provided green grass during stall feeding. Maximum farmers (82\%) of central region supplied concentrate feed but $61 \%$ farmers of southern region did not supply concentrate to their goat. Farmers (82\%) of central region provided particular feeder but $67.7 \%$ farmers of southern region did not provide feeder during concentrate feeding. Most of the farmers of both region supplied water daily to their goat. Tube well (84\%) was the main source of water of goat at central part of Bangladesh. Source of water in southern region were (46.3\%) tube well and (51.2\%) pond. However, $76 \%$ farmers of central region supplied green tree leaves and $24 \%$ farmers supplied both green grass and tree leaves while, $46.3 \%, 19.5 \%$ and $34.1 \%$ farmers of southern part of Bangladesh supplied green tree leaves, green grass and both, respectively, to their goats. Most of the farmers $(90 \%)$ of central region grazed their goat but $70.7 \%$ farmers did not graze their goat during rain time. Hossain $e t$ al. (2015) reported that $61 \%, 19.5 \%$ and $19.5 \%$ goat rearing farmers were supplied green grass, green grass and straw; and green grass and concentrate, respectively. They also found that $65.9 \%$ of farmers supplied green grass while $39 \%$ farmers supplied concentrate feed to their goats during keeping goats inside house. Drinking water sources were (46.3\%) tube well, (51.2\%) pond and (2.4\%) supply water (Hossain et al., 2015). They also reported during rainy season goat rearing farmers in the southern region supplied $(46.3 \%)$ green tree leaves, $(19.5 \%)$ green grass and $(34.1 \%)$ green tree leaves and green grass to their goats but at rain time $29.3 \%$ farmers grazed their goats. Few farmers used improved pastures or concentrates to enhance the nutrition of their goats (Pattamarakha et al., 1997). The above discussions might be suggested that farmers at central region were more careful of their goats in regards of feeds and feeding, water sources and watering then southern regions. 
Table 1. Rearing management system of goat at Central and Southern region of Bangladesh.

\begin{tabular}{llll}
\hline Parameters & Category & Central region & Southern region \\
\cline { 3 - 4 } Rearing system & & No. of farmers (\%) & No. of farmers (\%) \\
\cline { 2 - 3 } & Confinement & $0(0 \%)$ & $3(7.3 \%)$ \\
& Semi intensive & $50(100 \%)$ & $33(80.5 \%)$ \\
& Free range & $0(0 \%)$ & $5(12.2 \%)$ \\
Night shelter & Goat's house & $34(68 \%)$ & $31(75.6 \%)$ \\
& Cattle's house & $4(8 \%)$ & $2(4.9 \%)$ \\
Provide bedding material during & Yes & $8(16 \%)$ & $8(19.5 \%)$ \\
winter season & Veranda of farmers living room & $4(8 \%)$ & $0(0 \%)$ \\
Bath during summer season & No & $49(98 \%)$ & $32(78 \%)$ \\
& Yes & $1(2 \%)$ & $9(22 \%)$ \\
Bath during winter season & No & $42(84 \%)$ & $41(100 \%)$ \\
& Yes & $8(16 \%)$ & $0(0 \%)$ \\
& No & $9(18 \%)$ & $18(43.9 \%)$ \\
\hline
\end{tabular}

Table 2. Feeding management of goat at Central and Southern region of Bangladesh.

\begin{tabular}{|c|c|c|c|}
\hline Parameters & Category & Central region & Southern region \\
\hline \multirow[t]{4}{*}{ Feed ingredients } & & No. of farmers (\%) & No. of farmers (\%) \\
\hline & Green grass & $9(18 \%)$ & $25(61 \%)$ \\
\hline & Green grass and concentrate & $41(82 \%)$ & $8(19.5 \%)$ \\
\hline & Green grass and straw & $0(0 \%)$ & $8(19.5 \%)$ \\
\hline \multirow[t]{2}{*}{ Stall feeding with green grass } & Yes & $40(80 \%)$ & $27(65.9 \%)$ \\
\hline & No & $10(20 \%)$ & $14(34.1 \%)$ \\
\hline \multirow{2}{*}{ Concentrate supply } & Yes & $41(82 \%)$ & $16(39 \%)$ \\
\hline & No & $9(18 \%)$ & $25(61 \%)$ \\
\hline \multirow{2}{*}{$\begin{array}{l}\text { Particular Feeder for concentrate } \\
\text { feeding }\end{array}$} & Yes & $41(82 \%)$ & $13(31.7 \%)$ \\
\hline & No & $9(18 \%)$ & $28(67.7 \%)$ \\
\hline \multirow[t]{2}{*}{ Watering daily } & Yes & $44(88 \%)$ & $37(90.2 \%)$ \\
\hline & No & $6(12 \%)$ & $4(9.8 \%)$ \\
\hline \multirow[t]{2}{*}{ Watering frequency per day } & Once & $43(86 \%)$ & $23(56.1 \%)$ \\
\hline & Not counted & $7(14 \%)$ & $18(43.9 \%)$ \\
\hline \multirow{5}{*}{ Drinking water sources } & Tube well & $42(84 \%)$ & $19(46.3 \%)$ \\
\hline & Pond & $1(2 \%)$ & $21(51.2 \%)$ \\
\hline & Pond and lake & $2(4 \%)$ & $0(0 \%)$ \\
\hline & Tube well and pond & $5(10 \%)$ & $0(0 \%)$ \\
\hline & Supply water & $0(0 \%)$ & $1(2.4 \%)$ \\
\hline \multirow[t]{3}{*}{ Feeding during rainy day } & Green tree leaves & $38(76 \%)$ & $19(46.3 \%)$ \\
\hline & Green grass & $0(0 \%)$ & $8(19.5 \%)$ \\
\hline & Green grass and tree leaves & $12(24 \%)$ & $14(34.1 \%)$ \\
\hline \multirow{2}{*}{ Graze in the rain time } & Yes & $45(90 \%)$ & $12(29.3 \%)$ \\
\hline & No & $5(10 \%)$ & $29(70.7 \%)$ \\
\hline
\end{tabular}

Table 3. Breeding management of goat at Central and Southern region of Bangladesh.

\begin{tabular}{llll}
\hline Parameters & Category & $\begin{array}{l}\text { Central region } \\
\text { Nos. of farmers (\%) }\end{array}$ & $\begin{array}{l}\text { Southern region } \\
\text { Nos. of farmers }(\%)\end{array}$ \\
\hline Buck keeping & Yes & $0(0 \%)$ & $8(19.5 \%)$ \\
& No & $50(100 \%)$ & $33(80.5 \%)$ \\
Service done by & Village buck & $46(92 \%)$ & $29(70.7 \%)$ \\
& Farmers buck & $0(0 \%)$ & $8(19.5 \%)$ \\
& BAU buck & $4(8 \%)$ & $0(0 \%)$ \\
& Own buck & $0(0 \%)$ & $3(7.3 \%)$ \\
Service fee of village buck & Artificial Insemination & $0(0 \%)$ & $1(2.4 \%)$ \\
& Service charge received & $50(100 \%)$ & $30(73.2 \%)$ \\
Close breeding practice & No service charge taken & $0(0 \%)$ & $11(26.8 \%)$ \\
& Yes & $50(100 \%)$ & $0(0 \%)$ \\
& No & $0(0 \%)$ & $41(100 \%)$ \\
\hline
\end{tabular}




\subsection{Breeding management}

All farmers (100\%) of central region did not keep buck but only $19.5 \%$ farmers of southern region kept buck for breeding their female goat. Ninety two percent famers of central part of Bangladesh and $70.7 \%$ farmers of southern region used village buck for breeding their female goat. However, all farmers used natural mating systems to serve their does but $12 \%$ farmers of Mymensingh depended on artificial insemination in goat (Khandoker et al., 2011). Most of the buck keeping farmers (100\%) received service charge during breeding and they also practiced close breeding method in the central region. Most of $(73.2 \%)$ the buck keeping farmers of southern region received service charge of buck and $26.8 \%$ did not receive service charge during breeding of female goat and they did not practice close breeding system. Hossain et al. (2015) found that majority of goat keepers $(70.7 \%)$ used village buck to inseminate their does and most of the farmers $(73.2 \%)$ gave service charge to the buck keepers while, most of the farmers $(80.5 \%)$ did not keep bucks for breeding. The present study might be indicative that farmers at central region of Bangladesh were less attentive to keep breeding bucks of their own and they were also less aware of inbreeding depression in their goats then the farmers of southern region.

\section{Conclusions}

Most of the goat rearing farmers in central and southern region of Bangladesh reared goats in semi-intensive system and kept their goats at goat's house. Farmers of central and southern region took winter care of their goats and took bath of their goats during summer. The above discussions might be suggested that farmers at central region were more careful of their goats in regards of feeds and feeding, water sources and watering than southern regions. On the contrary, farmers at central region of Bangladesh were less attentive to keep breeding bucks of their own and they were also less aware of inbreeding depression in their goats than the farmers of southern region.

\section{Acknowledgements}

Authors are grateful to the goat farmers of the study areas for their cooperation in participating and answering predesigned questionnaires about rearing, feeding and breeding of goats to meet the objective of the study.

\section{Conflict of interest}

None to declare.

\section{References}

Afroz MF, 2007. Genetic variation in different goat population of Bangladesh based on Microsatellite markers. MS thesis, Department of Animal Breeding and Genetics, Bangladesh Agricultural University, Mymensingh. pp. 1-102.

Amin MR, 2000. Genetic Improvement of Production Traits in Bangladesh Goats by Selective breeding and Crossbreeding. PhD thesis, Department of Animal Breeding and Genetics, Bangladesh Agricultural University, Mymensingh. pp. 1-242.

DLS (Department of Livestock Services), 2004. Livestock statistics of Bangladesh. Ministry of Fisheries and Livestock, Govt. of Peoples Republic of Bangladesh.

Draft SFYP, 2010. Planning Commission, Government of Bangladesh. The Draft sixth five Year Plan (20112015), Dhaka. Paper presented at the workshop held on 6th January, 2010 in DLS conference room.

FAO, 2003. Production year book 2003, vol. 57:210, 231, 216

FAOSTAT, 2009, http://faostat. Fao.org/default. aspx.

Faruque MO, 2009. Final report of research project entitled "Gene based technologies in livestock breeding": phase 1- Characterization of small Ruminant Genetic Resource in Asia. International Livestock Research Institute Vienna, 37.

Hossain MS, A Akhtar, MH Hossain, MP Choudhury and F Islam, 2015. Goat husbandry practices in Southern region of Bangladesh. J. Biosci. Agric. Res., 05: 59-64.

Khandoker MAMY, AS Apu, SS Husain and DR Notter, 2011. A baseline survey on the availability of Black Bengal breeding bucks in different districts of Bangladesh. J. Bangladesh Agril. Univ., 9: 91-96.

Pattamarakha K, J Tanapanyarachwong and S Saithanoo, 1997.The use of recommended goat husbandry practices by farmers in Southern Thailand. Asian-Aust. J. Anim. Sci., 10 : 587-592.

Peacock C, 2005. Goats- A Path way out of poverty. Small Rumi. Res., 60: 179-186.

SPSS, 2005. Windows for version-14.0. Release on 27.10.2005. (Microsoft Corp.1998). Trends SPSS Inc., Michigan Avenue, Chicago, IL. 19-182. 